\title{
Astronomia no Ensino Fundamental: Contribuições de uma Sequência Didática Sociointeracionista Pautada por Questionamentos
}

\author{
Cleci Teresinha Werner da Rosa* \\ Barbara Locatelli da Silva** \\ Luiz Marcelo Darroz ${ }^{* * *}$
}

\begin{abstract}
Resumo
O estudo envolve a inserção de temas relacionados à Astronomia no ensino fundamental a partir de perspectivas teóricas que primam pelas relações sociais e favoreçam a construção dos conceitos dentro de um processo dialético. $\mathrm{O}$ estudo parte do questionamento referente a que elementos são favorecidos em uma prática pedagógica sociointeracionista, tendo como objetivo analisar as potencialidades de um ensino pautado pela perspectiva sociointeracionista. Para tanto, foi estruturada uma sequência didática apoiada em questionamentos de forma a proporcionar a interação, o diálogo e a participação dos estudantes. A aplicação ocorreu em uma turma de sexto ano, em uma escola pública estadual no interior do Rio Grande Sul. A investigação tomou como instrumento o diário de bordo preenchido pela pesquisadora que assumiu a condição de professora da turma. Os dados obtidos foram analisados à luz dos processos de interação social, estabelecendo como categorias de análise: interação aluno/aluno, aluno/professor e aluno/material. Tais resultados apontam, na primeira categoria, que os estudantes puderam interagir de forma plena com seus pares, possibilitando uma interlocução e um diálogo voltados a trocas e construção de saberes; na segunda categoria, mostraram que os estudantes tiveram oportunidade e liberdade de interagir com a professora/pesquisadora de modo a fazer inferências e questionamentos que enriqueceram suas aprendizagens; e, na terceira categoria, evidenciaram a importância de utilizar materiais didáticos voltados à realidade de cada turma, trazendo elementos que possibilitam resgatar seus conhecimentos espontâneos e contextualizados com sua cultura. A conclusão do estudo aponta para o fato de os processos de interações favorecerem a dimensão cognição-afeto, ampliando as possibilidades de aprendizagem.
\end{abstract}

Palavras-chave: astronomia, ensino fundamental, sequência didática, interação social.

Astronomy in middle school: contributions of a social interactionist didactic sequence guided by questionings

\begin{abstract}
The research involves the insertions of themes related to Astronomy based on the theoretical perspectives which prime for social relations and promote the construction of concepts inside a dialectical process in Middle School. The study stems from the question referring to which elements are favored in a social interactionist pedagogical practice, having as its goal to analyze the potentialities of teaching guided by the social interactionist perspective. Therefore, a didactic sequence was structured based on questionings to provide interaction, dialogue and the participation of the students. The appliance was held in the sixth year of Middle School (Brazilian grading), in a public school in the countryside of Rio Grande do Sul. The investigation used as its tool a logbook filled in by the researcher who was in the position of teacher of the group. The obtained data was analyzed in light of the process of social interaction, establishing as analyses' categories: student-student interaction, student-teacher interaction and student-material interaction. The results point out, in the first category, that the students were able to fully interact with their pairs, making a interlocution and dialogue directed to the exchange of knowledge construction possible; in the second category, it was pointed that the students had the opportunity and freedom to interact with the

\footnotetext{
* Doutora em Educação Científica e Tecnológica. Docente Permanente do Programa de Pós-Graduação em Ensino de Ciências e Matemática - UPF. Docente Permanente do Programa de Pós-Graduação em Educação - UPF Universidade de Passo Fundo - RS. E-mail: cwerner@upf.br.

** Mestre em Ensino de Ciências e Matemática. Egressa do Programa de Pós-Graduação em Ensino de Ciências e Matemática - UPF Universidade de Passo Fundo - RS. E-mail: baa.lsilva@ hotmail.com.

*** Doutor em Educação em Ciências. Docente Permanente do Programa de Pós-Graduação em Ensino de Ciências e Matemática - UPF. Docente Permanente do Programa de Pós-Graduação em Educação - UPF Universidade de Passo Fundo - RS. E-mail: ldarroz@upf.br.
} 
teacher/researcher in a way to make questions and infer that improved their learning; and in the third category it was proved the importance of the usage of didactic materials that embrace the reality of each group, bringing elements that make possible to redeem their spontaneous knowledge and contextualized with their culture. The conclusion of the study points to the fact that the interaction processes favor the cognition-affect dimension, expanding the possibilities of learning.

Keywords: Astronomy, middle School, didactic sequence, social interaction.

\section{Introdução}

O ensino de Astronomia tem sido foco de interesse por parte de pesquisadores que buscam evidenciar a importância e viabilidade de conteúdos desse campo do conhecimento nos diferentes níveis educacionais, em particular no ensino fundamental. Mees (2004), por exemplo, afirma que esses conteúdos contribuem para aguçar a curiosidade das crianças, assim como dos jovens e adultos. Nas palavras do autor:

\footnotetext{
Este tema, cada vez mais, está presente no nosso cotidiano, pois, quase que diariamente, a mídia veicula novas informações capturadas por sondas espaciais que exploram o nosso Sistema Solar [...]. É também um tema apaixonante nas suas múltiplas abordagens interdisciplinares: história, mitologia, literatura, filosofia, ecologia, música e outros, e representa a busca da humanidade pelo autoconhecimento (ibidem, p. 10).
}

No viés da viabilidade de abordar esses temas com estudantes desde o ensino fundamental, temos o estudo de Amaral (2015) que busca mostrar que os conteúdos de Astronomia aparecem no planejamento e no livro didático das disciplinas de Ciências e de Geografia, entretanto, em ambos têm sido relegados a um segundo plano. Além disso, o estudo apontou que, quando esses conteúdos são trabalhados, os professores se prendem ao livro didático e pouco qualificam suas aulas com recursos diversificados: "Os conteúdos de Astronomia são trabalhados de forma sintetizada e desarticulada do cotidiano do aluno, com o auxílio de material didático que contém informações, em grande parte, incoerentes e limitadas" (AMARAL, 2015, p. 34).

Outro aspecto que pode contribuir para que os conteúdos de Astronomia sejam explorados de forma incipiente e com poucos resultados expressivos, em termos da construção de conceitos neste campo, são as poucas propostas didáticas presentes na literatura e ao alcance dos professores. Em um levantamento realizado pelas autoras do presente artigo junto ao Banco de Teses e Dissertações da Capes e em revistas 
especializadas na temática no período de 2007 a 2017, foram localizadas seis pesquisas em que são descritas possibilidades de inserção dos conteúdos. Todavia, tais estudos se mostram limitantes em termos de enfatizar a perspectiva sociocognitivista como referencial de abordagem.

A importância dessa abordagem reside no fato de que o elemento norteador das ações está no diálogo e na interação com seus colegas, com o material didático e com o professor. Tal perspectiva teórica tem ganhado espaço nos estudos envolvendo práticas de ensino, e se mostra relevante, uma vez que o sociointeracionismo pressupõe, como destacado por Castorina et al. (1998), que a aprendizagem está associada à interação social, na qual, por meio das relações, os sujeitos trocam ideias, leituras e experiências que culminarão na construção de conhecimentos. Além disso, tal perspectiva teórica sublinha a importância de resgatar questões históricas e culturais, particularmente presentes quando se trata da Astronomia.

Nesse sentido, consideramos que a escola representa um espaço privilegiado para a sistematização e confronto dos conhecimentos que os alunos trazem de suas vivências e do meio em que estão inseridos, e que são adquiridos de forma espontânea e ligados a sua cultura. Portanto, torna-se fundamental promover situações didáticas que possibilitem a troca e a interação entre os sujeitos envolvidos.

Dessa constatação, especialmente do entendimento de que a aprendizagem é um ato social de troca e de ajuda mútua, surge o questionamento que subsidia o presente estudo: que elementos são favorecidos em uma prática pedagógica sociointeracionistas?

Tal questionamento compele ao estudo o objetivo de analisar as potencialidades de um ensino pautado pela perspectiva sociointeracionista para abordar tópicos de Astronomia no ensino fundamental - anos finais. De forma mais específica, o estudo objetiva analisar a elaboração e aplicação de proposta didática voltada a abordar tópicos de Astronomia no sexto ano do ensino fundamental.

Para alcançar o objetivo, desenvolvemos uma sequência de ensino estruturada a partir do sociointeracionismo, cuja avaliação ocorre por meio de uma pesquisa qualitativa e participante. Como instrumentos para coleta de dados, foi utilizado o diário de bordo preenchido pela pesquisadora que assumiu a condição de pesquisadora. 


\section{Sociointeracionismo}

Nesta perspectiva teórica, entendemos que o desenvolvimento de um sujeito está associado à interação dele com o meio em que vive e com os demais integrantes desse meio, frente a uma relação mediada pelos símbolos e instrumentos utilizados no grupo, cada qual com seu significado específico atrelado à estrutura cultural desse grupo. A estrutura mental do indivíduo será formada tomando-se como base a sua história social. Não há, segundo esta concepção de desenvolvimento cognitivo, uma relação de aprendizagem que ocorra em uma via de mão única, e nem é possível desprezar o ambiente sociocultural onde o sujeito está inserido.

A concepção de formação de um sujeito interagindo dialeticamente com o meio em que vive, aprendendo e reaprendendo todo o tempo, é a base da teoria proposta por Lev Semenovich Vigotski no início do século XX. Para ele, os conceitos são construídos pela pessoa que aprende, baseados na cultura em que ela se insere. Esta relação é dialética, por conter uma via de mão dupla em que o indivíduo se transforma ao mesmo tempo em que transforma seu ambiente.

A escola se torna um ambiente favorecedor desse desenvolvimento, uma vez que oportuniza as relações. De acordo com Palangana (2001, p. 8):

\footnotetext{
As interações sociais de um modo geral e em particular aquelas que ocorrem no âmbito escolar vêm sendo apontadas como um caminho através do qual é possível incrementar o processo de aprendizagem e desenvolvimento, tornando mais produtivo o impacto da escola na trajetória de vida do sujeito.
}

A importância da escola se revela em suas múltiplas dimensões, inclusive na orientação de suas propostas pedagógicas. Nelas, e frente a um viés que deseja favorecer o desenvolvimento dos indivíduos, torna-se fundamental considerar a bagagem intelectual dos estudantes, preocupando-se em ampliar as estratégias de seus pensamentos.

Ainda nessa concepção, Tudge (1996) mostra que é fundamental que a escola considere que os estudantes chegam com conhecimentos prévios, priorizando em suas propostas de sala de aula a interação, a fim de que eles possam estabelecer relações entre conhecimento espontâneo e o conceito formal.

Sobre isso Vigotski (1984, p. 93) afirma que: 


\begin{abstract}
A criança adquire consciência dos seus conceitos espontâneos relativamente tarde; a capacidade de defini-los por meio de palavras, de operar com eles à vontade, aparece muito tempo depois de ter adquirido os conceitos. Ela possui o conceito [...], mas não está consciente do seu próprio ato de pensamento. $\mathrm{O}$ desenvolvimento de um conceito científico, por outro lado, geralmente começa com sua definição verbal e com sua aplicação em operações não-espontâneas. [...] Poder-se-ia dizer que o desenvolvimento dos conceitos espontâneos da criança é ascendente, enquanto o desenvolvimento dos seus conceitos científicos é descendente.
\end{abstract}

Frente ao mencionado a aprendizagem é entendida como vinculada a um processo de interação entre sujeito e objeto. Todavia, para Piaget, o desenvolvimento da criança, está associado às relações entre as estruturas biológicas e o meio social, embora priorize as primeiras relações. De acordo com Rodrigues e Melchiori (s/data), Piaget foi um dos grandes estudiosos do cognitivismo, partindo do pressuposto de que

\begin{abstract}
o desenvolvimento não pode ser dissociado do crescimento físico e defende que há um paralelismo entre eles. A inteligência, para Piaget, modifica-se à medida que a criança se desenvolve e parte de um continuum entre reflexos biológicos, movimentos espontâneos e hábitos adquiridos [...]. É, portanto, um processo de conhecimento que tem como material tanto a informação do meio em que vivemos quanto o que já está registrado na nossa memória, ou seja, a inteligência se constrói a partir da interação entre o organismo e o ambiente (p. $3)$.
\end{abstract}

Vigotski, diferentemente, tratou o desenvolvimento da criança como um processo de internalização de suas relações sociais. Tais relações vividas por cada sujeito, como expresso por Marx e Engels (1999), resultarão em funções psicológicas, formando assim, sua personalidade.

O homem é, portanto, um ser ativo em seu tempo, em seu momento histórico e em seu meio social, ou seja, ele constrói sua cultura, faz sua história, e é, ao mesmo tempo, influenciado por ela. Ou seja, nas palavras de Marx e Engels (1999, p. 37): “[N]ão é a consciência que determina a vida, mas a vida que determina a consciência”. Nessa concepção, o ponto de partida é aquilo que os autores denominam de "vida real". Tudo isso está proposto nas ideias dos autores sobre as relações homem/natureza, e Vigotski associará tais ideias ao campo da psicologia, mostrando como o ser humano é capaz de transformar a natureza e, ao mesmo tempo, transformar a si mesmo por meio de seu trabalho e por meio de instrumentos mediadores, sejam concretos ou psicológicos (COLE; SCRIBNER, 2007). 
Vigotski busca uma compreensão dos processos formadores das estruturas psicológicas superiores, atribuindo maior ênfase à história cultural do homem. Essa relação do homem com a natureza e sua ação transformadora sobre ela estabelecerão o que irá ocorrer no desenvolvimento do ser humano. Temos, portanto, a inferência de que, no momento em que o homem precisa lutar pela sua sobrevivência, ele acaba por se organizar "em torno do trabalho" (PALANGANA, 2001, p. 111) e, por isso, cria relações com seus semelhantes e com a natureza à sua volta. A produção guiará a forma de vida social, política e econômica. A forma de pensar e a formação das ideias também ficarão condicionadas a toda essa estrutura. Dessa forma, processos como cognição, percepção, estruturação da personalidade, emoção, memória, desenvolvimento e até mesmo psicopatias serão elucidados e entendidos dentro da lógica do sociointeracionismo (RATNER, 2002, p. 6).

A estrutura biológica do ser humano servirá de base para a formação de sua consciência a partir de suas relações com os outros e com a natureza. A respeito da consciência, entende-se que, conforme mencionado por Luria, citado por Vigotski (2003, p. 196): “[...] é a habilidade em avaliar as informações sensoriais, em responder a elas com pensamentos e ações críticas e em reter traços de memória de forma que traços ou ações passadas possam ser usados no futuro".

Vigotski ao desejar entender como a linguagem pode favorecer a ativação das funções psicológicas superiores, discute como essa linguagem vai interferir na dinâmica social e na evolução do pensamento humano. Para ele, o homem se relaciona socialmente e, em seguida, traz o resultado de tais relações para dentro de si, sendo assim, a natureza social das pessoas converte-se na natureza psicológica de cada uma delas (SOUZA, 2004). Para isso, é necessária a existência de mediadores, sejam instrumentos ou símbolos.

Segundo Daniels (2003), Vigotski classificou as formas de mediação em três classes, assim identificadas: meios materiais, meios psicológicos e outras pessoas. No seu estudo, o autor identifica que, em relação ao uso do livro paradidático como forma de mediação, pode-se entender que os três elementos entram em cena. Segue o autor mencionando que, no entender de Vigotski, a linguagem, os símbolos, os diagramas e os desenhos representam "ferramentas psicológicas". E, por fim, têm-se as atividades exercidas pelo professor ou até mesmo por alunos mais desenvolvidos, que representam 
o terceiro elemento mediador - outras pessoas. Trata-se, portanto, de uma ferramenta muito rica para o desenvolvimento de um trabalho em sala de aula.

A importância da linguagem e dos signos está associada ao uso da comunicação verbal. Ao expressar-se verbalmente, o indivíduo está, de fato, dando significado à palavra, ou seja, está unindo pensamento e fala (VIGOTSKI, 2005, p. 5). A palavra e seu significado, dentro de certo contexto, possibilitam ao indivíduo se comunicar em seu meio social. Para o autor, a palavra é, portanto, "uma unidade tanto necessária ao pensamento generalizante quanto ao intercâmbio social, ou seja, instrumento imprescindível à mediação homem/mundo" (2005, p. 8).

Em relação à mediação feita por uma pessoa no ambiente escolar, o indivíduo mais experiente que pode ser o professor, estimulará os outros "não só na apropriação da linguagem, como também na sua expansão" (MARTINS, 1997, p. 116). Cabe ao mediador estabelecer estratégias para a promoção da expansão das capacidades apresentadas inicialmente pelo aluno. Tal inferência é mencionada por Vigotski ao alertar que se deve analisar a relação entre aprendizagem e desenvolvimento, e atentar para aspectos específicos dessa relação para o indivíduo em idade escolar, pois, o aprendizado não espera que o indivíduo chegue à escola, começando antes, na interação da pessoa com o seu ambiente, com sua cultura e com as outras pessoas e objetos que fazem parte desse conjunto, e o aprendizado escolar, além de ter uma estrutura própria, diferente da não escolar, evidenciará que há uma região de domínio de habilidades que o indivíduo possui quando age individualmente e outra região onde ele desenvolverá atividades apenas com a ajuda de outra pessoa (VIGOTSKI, 2005).

Fica claro neste ponto a ideia de que há um nível de conhecimento que o aluno já domina e outro que ele pode atingir com a ajuda de indivíduos mais experientes, como é o caso do professor no contexto escolar. A região que separa tais níveis é definida por Vigotski (1984, p. 87) como "zona de desenvolvimento proximal” - ZDP, ou, como expressa nas palavras do autor:

[...] a distância entre o nível de desenvolvimento real, que se costuma determinar através da solução independente de problemas, e o nível de desenvolvimento potencial, determinado através da solução de problemas sob a orientação de um adulto ou em colaboração com companheiros mais capazes. 
Aprender, nesse sentido, está relacionado a uma ampliação do campo de conhecimento do aluno, levando-o a penetrar nas regiões onde antes ele só poderia fazêlo com o auxílio de um mediador. Depois que Vigotski elaborou este conceito, há mais de 80 anos, a integração de crianças em diferentes níveis de desenvolvimento passou a ser encarada como um fator determinante no processo de aprendizado.

\section{Aspectos metodológicos e sequência didática}

Para o desenvolvimento da proposta didática, parte-se da realidade de uma escola pública estadual no município de Carazinho - RS, que oferece no turno da manhã turmas de $5^{\circ}$ ao $9^{\circ}$ ano do Ensino Fundamental, e à tarde, turmas de Educação Infantil. A turma selecionada foi a do $6^{\circ}$ ano do ensino fundamental, considerando que no planejamento anual contavam conteúdos vinculados a Astronomia dentro do componente curricular de Ciências, bem como no componente curricular de Geografia. Na primeira, os conteúdos identificados como relacionados ao tema foram: Sistema Solar; estrelas, constelações e galáxias; e Planeta Terra e sua origem. No componente curricular Geografia, os conteúdos identificados foram: Movimento de Rotação e Translação da Terra; Fases da Lua; Estações do Ano; e Eclipses.

A partir dessa identificação e em contato com as professoras dessas disciplinas, foi acordado que a sequência didática se ocuparia dos conteúdos relacionados ao planejamento da disciplina de Ciências, incluindo os temas Movimento de Rotação e Translação da Terra e Fases da Lua. As Estações do Ano e Eclipses ficaram a cargo da professora de Geografia, atendendo a sua solicitação e, portanto, não foram incluídos na sequência didática apresentada neste estudo.

A turma de $6^{\circ}$ ano selecionada de forma aleatória, entre as duas existentes na escola, estava integralizada por quinze alunos, sendo cinco meninos e dez meninas. A grande maioria dos alunos são moradores das proximidades da escola e já frequentam esse ambiente há seis anos. Uma das alunas tinha acabado de chegar à escola por transferência de outro estado (Santa Catarina). A turma apresenta faixa etária de onze a quatorze anos, sendo que: onze alunos estavam com onze anos; três, com doze anos; e um aluno, com quatorze anos. 
A estruturação da sequência didática priorizou conteúdos que permitissem ser abordados dentro de uma sequência lógica, e que oportunizassem o desenvolvimento das estruturas mentais. Nesse sentido, tomamos como referência o entendimento de que uma sequência didática, segundo Amaral (2009, p. 1), representa "um conjunto de atividades ligadas entre si, planejadas para ensinar um conteúdo, etapa por etapa”. Esse conjunto de atividades apoia-se na necessidade de que as discussões dos conhecimentos em uma perspectiva sociointeracionista são favorecidas quando se parte de questionamentos, pois eles possibilitam o resgate dos conhecimentos espontâneos dos alunos, especialmente os vinculados aos processos históricos e culturais.

Para tanto, buscamos em Rosa (2011) subsídio para estruturar os encontros de modo a privilegiar os questionamentos como aspecto introdutório das atividades desenvolvidas. No estudo desenvolvido pela autora, é evidenciado que esses questionamentos podem ser representados pela "formulação de perguntas sobre o conteúdo, exposição de situações-problema ou situações-ilustrativas e retomada histórica" (p. 141). No caso da apresentação de perguntas, opção do presente estudo, a autora infere que "encontra-se associada à formulação de questões segundo estudos teóricos, estando relacionada a uma metodologia dialética na qual o professor apresenta questões e orienta os estudantes a discutir possibilidades" (p. 141).

Acrescentamos a isso que a formulação de perguntas diretas, como questionamento inicial na abordagem dos conteúdos, oportuniza que os alunos dialoguem e exponham seus conhecimentos prévios (espontâneos) sobre o assunto. Esses questionamentos (perguntas) devem oportunizar a formulação de hipóteses acerca da problemática apresentada, e, a partir de então, realizar as atividades em si.

A partir dessas escolhas elaboramos a sequência didática, estruturando um conjunto de atividades para ser desenvolvido em cinco encontros, perfazendo um total de dez horas/aula. Tal organização em cinco encontros decorre do tempo concedido pela professora titular da turma, que se justifica em função do seu planejamento anual para os demais conteúdos. Cabe ainda mencionar que a professora titular da turma participou dos encontros de planejamento das atividades, mas não participou das aulas.

Diante desse contexto e somando ao fato de que a professora de Geografia abordaria alguns dos tópicos relacionados à Astronomia, planejamos os conteúdos a ser contemplados. Esses encontros foram ministrados no período de março a abril de 2018. 
O Quadro 1 ilustra as atividades e o abordado em cada encontro.

Quadro 1 - Cronograma, atividades desenvolvidas e perguntas norteadoras dos encontros

\begin{tabular}{|c|c|c|c|}
\hline Encontro & $\begin{array}{l}\text { Número } \\
\text { de } \\
\text { períodos }\end{array}$ & Atividades & Perguntas $^{2}$ \\
\hline 1 & 2 & 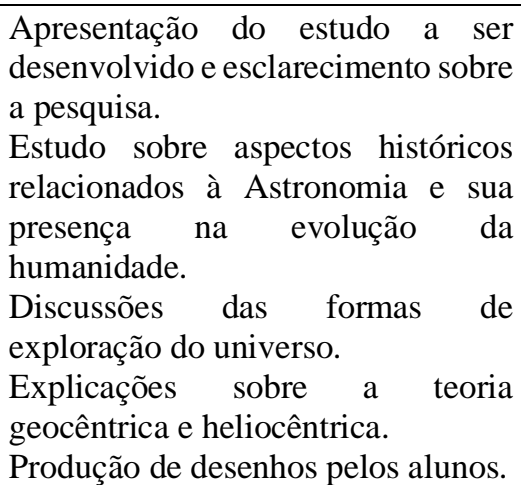 & $\begin{array}{l}\text { Vocês sabem o que é Astronomia? } \\
\text { Já estudaram algo sobre? } \\
\text { Ela tem alguma influência sobre a } \\
\text { vida diária de vocês? } \\
\text { Como vocês imaginam o Universo? } \\
\text { Como vocês imaginam nossa } \\
\text { Galáxia Via Láctea? } \\
\text { Como vocês imaginam o Planeta } \\
\text { Terra? }\end{array}$ \\
\hline 2 & 2 & $\begin{array}{l}\text { Projeção do filme Perdido em Marte } \\
\text { e registros dos alunos sobre cenas } \\
\text { instigantes apresentadas } \\
\text { relacionadas à Astronomia }{ }^{3} \text {. }\end{array}$ & $\begin{array}{l}\text { Que cenas do filme relacionadas a } \\
\text { Astronomia você gostaria de discutir } \\
\text { na próxima aula? }\end{array}$ \\
\hline 3 & 1 & $\begin{array}{l}\text { Discussões e pesquisas sobre } \\
\text { conteúdos explorados em cenas do } \\
\text { filme e selecionados pelos alunos. } \\
\text { Introdução ao estudo dos planetas e } \\
\text { demais corpos celestes a partir de } \\
\text { cenas previamente selecionadas pela } \\
\text { pesquisadora e vinculadas ao filme } \\
\text { projetado. }\end{array}$ & $\begin{array}{l}\text { Quais as cenas selecionadas por } \\
\text { vocês? }\end{array}$ \\
\hline 4 & 3 & $\begin{array}{l}\text { Continuidade do estudo sobre os } \\
\text { planetas. } \\
\text { Estudos sobre o Sistema Solar e os } \\
\text { principais corpos celestes. } \\
\text { Apresentação de um áudio } \\
\text { envolvendo discussões sobre } \\
\text { Plutão }{ }^{4} \text {. } \\
\text { Realização de um jogo didático para } \\
\text { identificação dos planetas e demais } \\
\text { corpos celestes que compõe o } \\
\text { Sistema Solar } 5\end{array}$ & $\begin{array}{l}\text { O que vocês estão vendo? } \\
\text { O que vocês já conhecem? } \\
\text { Qual é a estrela central do Sistema } \\
\text { Solar? } \\
\text { Quantos planetas compõem o } \\
\text { Sistema Solar? } \\
\text { Quais são eles? } \\
\text { Qual a diferença entre planeta e } \\
\text { estrela? } \\
\text { E sobre cometa, asteroides e } \\
\text { meteoros o que vocês sabem? }\end{array}$ \\
\hline
\end{tabular}

${ }^{1}$ Cada período corresponde a 45 minutos.

${ }^{2}$ As perguntas descritas no item são as realizadas durante os respectivos encontros em seus diferentes momentos e tomam como referência os estudos de Amaral (2015).

${ }^{3} \mathrm{O}$ filme do gênero Drama e Ficção Científica tem por título original The Martian, e é de autoria do cineasta Ridley Scott, com participação de Matt Damon, Jessica Chastain e Kristen Wiige.

${ }^{4}$ Disponível em: https://bit.ly/2SrpGEW. Acesso em:7 jan. 2018.

${ }^{5}$ Disponível em: https://bit.ly/2SRiOWB. Acesso em: 10 fev. 2018. 


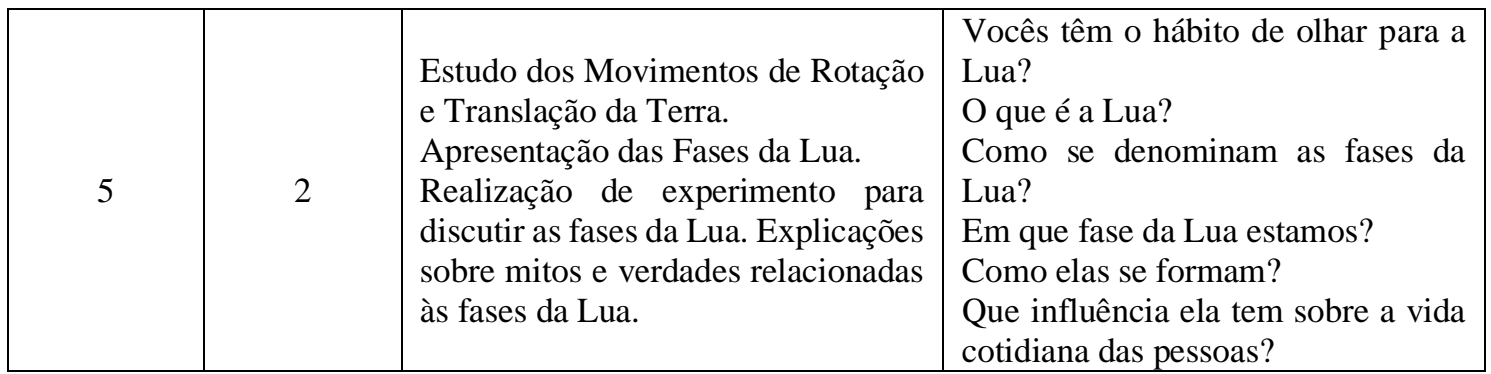

Fonte: autora, 2018.

A pesquisa associada à aplicação dessa sequência didática é de abordagem qualitativa que, segundo Richardson (1999, p. 102):

Não reside na produção de opiniões representativas e objetivamente mensuráveis de um grupo; está no aprofundamento da compreensão de um fenômeno social por meio de entrevistas em profundidade e análises qualitativas da consciência articulada dos atores envolvidos no fenômeno.

Além disso, a pesquisa é de natureza participante, seguindo o proposto por Gil (2008), uma vez que a pesquisadora assumiu a condução da sala de aula e foi a observadora, tomando como aspecto central a interação dela com os demais integrantes investigados. Tais características vêm ao encontro do pretendido neste estudo, pois, é por meio da participação, do diálogo, da troca de conhecimentos que será analisada a potencialidade da sequência didática como favorecedora da interação dos alunos.

Em relação ao instrumento para coleta dos dados, destacamos que o estudo recorreu ao uso do diário de bordo, com registros efetuados pela pesquisadora sobre suas observações no transcorrer da aula. O uso do diário toma como referencial o proposto por Zabalza (2004), em que o professor irá anotar todos os detalhes, anseios e questionamentos que surgiram durante os encontros. Segundo o autor, tais registros podem servir de material de pesquisa ou de reflexão para o professor. Nesse contexto, os registros feitos ao término de cada encontro serviram como material de coleta de dados e estão sendo cuidadosamente analisados com objetivo de subsidiar a busca por responder ao questionamento deste estudo. Esses registros envolvem as reflexões sobre as atividades realizadas, bem como características da estruturação dessas, participação e envolvimento dos alunos com o objeto de estudo.

A escolha do diário de bordo como instrumento para produção dos dados decorre da natureza qualitativa e interpretacionista do estudo desenvolvido. Nele buscamos 
analisar, à luz das percepções do pesquisador, quais os movimentos causados pela proposta didática estruturada para o estudo, particularmente em termos das interações entre os envolvidos.

Para discutir os resultados obtidos buscamos apoio na perspectiva da interação social, especialmente na perspectiva de Vigotski. Com a leitura do material coletado, foi possível identificar três elementos que circunscreveram essa produção, estando relacionados às interações, objeto de particular interesse neste estudo. São eles: as relações aluno/aluno, aluno/professor e aluno/material.

Tais elementos constituem as categorias de análise do estudo, sendo a primeira associada às discussões que evidenciam que os alunos trocaram experiências e discutiram os conteúdos entre eles mostrando as contribuições desse processo para a apropriação dos conteúdos em Astronomia. A segunda categoria visava analisar as trocas ocorridas entre os alunos e a professora/pesquisadora como forma de investigar se propostas didáticas pautadas em questionamentos e diálogos podem ser favorecedoras da aprendizagem. E, por fim, a terceira categoria que está associada a interação entre aluno/material e que analisa as relações dos alunos com os materiais e atividades desenvolvidas, trazendo para discussão que o processo de aprendizagem passa pela escolha de atividades e materiais potencialmente significativos.

\section{Resultados e Discussões}

Está seção se ocupa de descrever os resultados encontrados, bem como proceder a discussões frente aos registros do diário de bordo da professora que é a pesquisadora.

\section{Interação aluno/aluno}

Para Vigotski (1984), a interação, principalmente a realizada entre indivíduos face a face, tem uma função central no processo de internalização. $\mathrm{O}$ autor, ao ressaltar a importância dessas interações para a aprendizagem, enfatiza que é da própria natureza do homem e é por meio dela que ele se transforma, humaniza-se. Continua mencionando que, ao realizar estas interações, é necessário o uso de signos e instrumentos que possibilitem que homem transforme o seu meio e se relacionem com os demais. Segundo 
Vigotski as atividades social e historicamente construídas, ao serem internalizadas pelo sujeito, possibilitam o desenvolvimento das funções psicológicas superiores, essenciais para o processo de aprendizagem.

No caso da interação aluno/aluno, suas representações coletivas expressam sua forma de pensamento elaborado, resultante de suas relações com os objetos que afetam. Portanto, é imperativo ressaltar que, na medida em que os alunos interagem, ocorre evolução de significados, sendo estes compartilhados. Nesse sentido, a proposição de atividades que possibilitem esse tipo de evolução da aprendizagem será discutida e analisada com base nos relatos feitos no diário de bordo.

Em uma perspectiva geral, foi observado que os alunos procederam às interações com seus pares, especialmente durante as atividades realizadas em dupla ou em pequenos grupos. Todavia, também pode ser destacado que durante as discussões coletivas, realizadas com todo o grupo, houve momentos de trocas entre eles, de compartilhamentos de ideias e também de situações, vivências, o que pode ser considerado como valioso no âmbito da categoria em análise.

Nas duplas e grupos de trabalho, a organização e a escolha dos integrantes que ocorreram de forma livre, proporcionaram que os alunos se aproximassem por afinidade, caracterizando outro momento de aproximação e de busca por interação. De acordo com Rosa (2001), os processos de interação são mais significativos quando os estudantes apresentam afinidades entre si. A afetividade, para a autora, é um dos componentes importantes quando se trata de recorrer à interação entre pares como favorecedora da aprendizagem. Tais aspectos se revelam presentes quando são analisados os registros do diário de bordo da pesquisadora. Nele, esses momentos mostram que a interação entre os alunos foi maior do que a interação que estes mantiveram com a professora, tendo as discussões sido marcadas por debates e troca de ideias, inclusive por divergências e pequenos conflitos, evidenciados no trecho a seguir do diário de bordo:

Para a atividade de hoje, os alunos foram organizados em duplas, com o intuito de discutirem e anotarem as características dos planetas, através do Jogo Sistema Solar II, para que ambos pudessem se auxiliar, enquanto um dava os comandos do jogo o outro fazia as anotações e comentários que achasse necessárias. Por ser um jogo, houve um pouco de tumulto na sala de aula, mas os alunos interagiram e conseguiram alcançar o objetivo proposto (DIÁRIO DE BORDO, 19/04/2018). 
Os momentos destacados revelam que a interação entre os alunos, tanto na forma de grupo como em pares, ocorreu durante as aulas ministradas, sendo de suma importância na construção do conhecimento. Castorina et al. (1998) menciona que as interações sociais que ocorrem no interior do contexto escolar, especialmente as decorrentes das relações entre os próprios alunos são as mais frutíferas, pois decorrem da liberdade de pensamento possibilitando a cada um organizar o seu próprio conhecimento.

Outro momento a ser destacado nesta categoria foi o de interação entre os alunos durante o trabalhado referente ao Planeta Anão (Plutão) e nas atividades relacionados ao Sistema Solar, em que foram abordados mitos e crenças. Tais momentos foram registrados no diário de bordo cujos fragmentos estão representados a seguir:

\footnotetext{
$\mathrm{Na}$ aula de hoje, pode ser observado como os alunos escutam muito a opinião de seus colegas, quando ouvimos um áudio explicando o porquê de Plutão ser considerado um Planeta Anão. Entre si começam a discutir se existiam mais planetas anões ou não. A turma toda queria falar e entre eles, começaram a discutir aquilo que já haviam escutado sobre o assunto (DIÁRIO DE BORDO, 19/04/2018).

Hoje realizamos uma atividade experimental em que os alunos individualmente podiam ver o fenômeno das fases da Lua acontecendo, sendo simulado em um experimento. Após as observações, começamos a discussão sobre as fases da Lua e seus mitos, em que se pôde observar os questionamentos e as histórias de mitos familiares, fazendo com que os alunos discutissem entre si os formatos e fases da Lua. Percebi que, quando eles estão discutindo entre si, as ideias parecem estar 'mais soltas' e 'livres', porque eles falaram intensamente, mesmo os mais quietos. Nos diálogos, havia uma intensa troca e inferências de cada um nas colocações do outro, possibilitando que a cada fala novas perguntas surgissem. Esse processo, por vezes, parece causar tumultos em sala de aula, mas percebi claramente a importância de deixá-los falar, questionar e se aventurar na discussão com o colega (DIÁRIO DE BORDO, 26/04/2018).
}

Os registros possibilitam inferir que houve interação entre aluno-aluno e que isto foi um importante aspecto favorecido pela proposta didática, especialmente por trazer para a sala de aula temas instigantes mediados pelo uso de questionamentos. Inclusive, esse momento pode ser considerado como o que proporcionou o maior número de interações em se tratando dos diálogos entre os estudantes.

Por fim, destacamos trechos da aula sobre Cometas, Asteroides, Planetas e Sistema Solar, na qual foram apresentadas aos alunos várias imagens referentes ao conteúdo, e eles deveriam discutir sobre o que se tratavam as mesmas: 


\begin{abstract}
Hoje realizamos uma atividade na qual os alunos deveriam entrar em um consenso sobre o que se tratava cada imagem referente aos componentes do Sistema Solar. Após as observações de cada imagem, começamos a discussão sobre a mesma, sobre o que os alunos estavam visualizando e o que eles achavam que eram. Percebi que, enquanto eles discutiam sobre o que viram, as concepções pareciam estar mais livres, porque todos os alunos se manifestaram. Podendo então todos entrarem no final em um consenso próximo ou igual, possibilitando a troca de ideias e conhecimentos entre eles, claro que toda discussão causa um alvoroço na sala mas por fim há um grande aprendizado (DIÁRIO DE BORDO, 19/04/2018).
\end{abstract}

Outra característica importante a ser ressaltada é a importância de o professor favorecer que as ideias dos estudantes fossem expostas e que os demais tenham espaços para debater, julgar e opinar sobre essas colocações, tudo organizado e respeitando o colega. A interação entre os pares ou aluno-aluno, é um aspecto que precisa ser considerado pelos professores, uma vez que a liberdade de diálogo e de confronto de ideias pode estar mais presente nesse tipo de interação que em outras atividades.

\title{
Interação aluno/professor
}

Vigotski (1984) defende a importância da mediação como elemento presente nos processos de aprendizagem. Tal mediação pode ser entendida como o papel exercido pelo professor ao fazer uso da linguagem, selecionar materiais e atividades mais adequadas para determinadas tarefas. De acordo com o autor: "[...] o caminho do objeto até a criança e desta até o objeto passa por outra pessoa" (p. 34). Por isso, o conceito de aprendizagem mediada confere um papel privilegiado ao professor.

Na perspectiva sociointeracionista de Vigotski (1984), o professor é o agente mediador que, utilizando-se da linguagem, do material cultural, dentre outros recursos, intervém e auxilia na construção e reelaboração do conhecimento do aluno, para que seu desenvolvimento se torne possível.

Ainda para o autor, o convívio com uma pessoa mais experiente pode estimular as potencialidades do aprendiz, ativando nele esquemas processuais cognitivos ou comportamentais. Assim, de modo geral, os alunos esperam por uma "relação de intersubjetividade". Esse convívio com os mais experientes possibilita que o aluno se sinta encorajado ou desafiado a realizar as tarefas propostas que em um primeiro momento não podem ser realizadas sozinha, mas que na interação com o mais capaz, nesse caso o professor, ele consegue fazer. O aluno, embora possa se sentir menos capaz, 
acolhe a assistência do professor e consegue realizar tarefas que não conseguiria sozinho. Essa troca, em termos de interação, é uma via de mão dupla, pois não apenas o aluno é favorecido, mas também o professor, uma vez que ele, a cada ação, a cada discussão do conteúdo, ganha experiência e discernimento, aperfeiçoando seus conhecimentos.

O professor tem papel fundamental na interação como subsídio para o processo de aprendizagem de seus educandos, pois ele faz o papel de mediador dando suporte às construções, que segundo Tassoni (2000, p. 6):

Considerando que o processo de aprendizagem ocorre em decorrência de interações sucessivas entre as pessoas, a partir de uma relação vincular, é, portanto, através do outro que o indivíduo adquire novas formas de pensar e agir e, dessa forma apropria-se (ou constrói) novos conhecimentos

De acordo com Barros (1996, p. 102-103), soma-se a isso os aspectos afetivos que são típicos de uma interação entre aluno e professor:

\begin{abstract}
Dependerá muito do professor a criação, em sala de aula, de um ambiente acolhedor, de liberdade, onde a criança possa se sentir segura ao apresentar suas ideias e ao defender seus pontos de vista, quando diferentes dos demais. Enfim, é necessário muito cuidado para não se criar um bloqueio emocional à matemática que poderá acompanhar a criança por toda a vida.
\end{abstract}

Para a autora o professor é responsável por promover um ambiente em que os estudantes tenham a alegria de aprender, em que suas descobertas e inferências, sejam reconhecidas e valorizadas. Em contexto com maior segurança, as crianças se sentem livres para dialogar, levantar hipóteses e interagir com o professor e com o conhecimento em discussão. Ramos (2001) mostra que essa interação entre o aluno e o professor quando mediado por sentimentos positivos pode ter impacto no rendimento acadêmico, contribuindo para reduzir as situações de fracassos escolares.

Em termos da interação com o professor, aspecto central dessa categoria, os registros no diário de bordo apontaram que os estudantes se sentiram livres para realizar suas inferências e apontamentos no decorrer das atividades, como evidenciado nos trechos apresentados a seguir:

Como ainda não conhecia os alunos, pedi que os mesmos se apresentassem, falando seus nomes, idade e outros, para que pudéssemos estreitar os laços e deixá-los mais confiantes com uma nova professora e, um novo conteúdo. Posteriormente passei a explicar a minha proposta de trabalho, os objetivos e 
as etapas em que iríamos desenvolver as atividades. Pude verificar nos alunos certa curiosidade e entusiasmo, pois o assunto era algo novo, mas ao mesmo tempo sentiam um certo medo. Pedi a eles quem já havia estudado ou lido algo sobre Astronomia, uma aluna comentou já ter estudado em outra escola e então sabia um pouco sobre, já a grande maioria relacionou a fatos cotidianos, esse diálogo inicial fez com que os alunos desmistificassem um pouco a Ciência (DIÁRIO DE BORDO, 22/03/2018).

Falamos, ainda no primeiro encontro, sobre os temas Universo, Via Láctea e Planeta Terra, onde os alunos ilustravam as respostas do que era pedido com desenhos, por ser o primeiro encontro ainda possuíam insegurança e pediam à professora a todo momento se o que estavam fazendo era certo, mas, ao final dos períodos, já pude perceber que as dúvidas e os questionamentos iam surgindo e que então estava passando confiança e segurança aos alunos (DIÁRIO DE BORDO, 22/03/2018).

Último dia em que trabalhei com a turma e, ao finalizar minhas aplicações, teve muitos pedidos para que continuasse com a turma, que os alunos gostariam de seguir com o conteúdo e com a forma que havíamos trabalhado. Isso mostra para mim que, de alguma maneira, impactei a vida desses estudantes (DIÁRIO DE BORDO, 26/04/2018).

O apresentado nesta categoria ilustra a presença de um processo de interação entre professor e aluno, mostrando que a base de um bom relacionamento acaba sendo a confiança que o professor passa ao seu aluno e o respeito de ambas as partes. Tal compreensão está alinhada com o entendimento de interação social anunciado na categoria anterior e sustentada por Vigotski. Nesse sentido, cabe destacar o quão significativo esse momento se revelou para a proposta em estudo, podendo ser considerado como um dos mais significativos momentos do estudo. Isso corrobora o entendimento de que os processos interativos representam aspectos mobilizadores da construção do conhecimento, especialmente nas negociações quanto aos objetivos e desenvolvimento de atividades pedagógicas.

Outro aspecto importante é que, a interação que ocorre em sala de aula, mediada pelo professor, é mais do que um encontro entre ele e os estudantes para a realização de atividades de aprendizagem. Obviamente trata-se de uma relação que envolve sentimentos com expectativas e desejos, aspectos relevantes nas relações humanas que envolvem trocas sociais e comunicação, como as atividades desenvolvidas em sala de aula. Portanto, mais do que favorecer o processo de construção do conhecimento, ou por conta dele, é que as relações entre professor e aluno notadamente devem estar voltadas a situações de interação social comprometidas com o respeito, a confiança e voltadas à autonomia e à liberdade de expressão. Cabe ao professor estimular as interações entre os sujeitos que constituem a sala de aula, para elevar o nível de compreensão de seus 
estudantes durantes esse ato de argumentar, sendo o professor o responsável por propiciar esse espaço em sala e conduzi-lo da forma que mais favoreça a elevação de significados.

É importante considerar a relação entre professor-aluno junto ao clima estabelecido em sala de aula, da relação de empatia do professor com os alunos, do saber ouvir, refletir, discutir frente às colocações e o nível de compreensão dos alunos. A interação do professor com os alunos frente a um clima de respeito e valorização possibilita que a sala de aula se transforme em um espaço de construção e reconstrução dos conhecimentos, respeitando a cultura de movimento e do grupo em que vive (PÉREZ GÓMEZ, 2000).

Paulo Freire, ao defender a importância das relações entre professor e aluno, aponta a valorização do diálogo como instrumento dessas relações e também na constituição dos sujeitos. Ao defender a ideia de uma prática educativa dialógica, ressalta que é o diálogo, enquanto fenômeno humano, capaz de mobilizar as ações dos sujeitos. Em suas palavras:

[...] o diálogo é uma exigência existencial. E, se ele é o encontro em que se solidarizam o refletir e o agir de seus sujeitos endereçados ao mundo a ser transformado e humanizado, não pode reduzir-se a um ato de depositar ideias de um sujeito no outro, nem tampouco tornar-se simples troca de ideias a serem consumidas pelos permutastes (FREIRE, 2007, p. 91).

Nesse contexto, entende-se que a qualidade de atuação da escola não pode exclusivamente depender somente da vontade de um ou outro professor. É necessária a participação efetiva e conjunta da escola, junto da família, do aluno e dos profissionais ligados à educação, de forma que o professor também entenda que o aluno não é um sujeito somente receptor dos conhecimentos "depositados", mas alguém que participa ativamente do processo de construção de seus próprios saberes.

Pelo exposto, infere-se que as abordagens metodológicas são as ações do professor pelas quais se organizam atividades de ensino para atingir objetivos de natureza cognitiva, referentes ao trabalho docente. Essas metodologias que fazem parte das escolhas do professor representam os meios pelos quais os professores escolhem para interagir com seus alunos. Opções por estratégias mais dialógicas possibilitam maior participação dos alunos, enquanto metodologias mais tradicionais, em que o professor representa o detentor do conhecimento, pouco favorecem a troca e o diálogo. 


\section{Interação aluno/material}

Dentro de uma visão sociocognitivista e cujo intuito esteja em proporcionar aos alunos um sentido, um significado ao conteúdo, espera-se que ao elaborar determinada atividade didática, o professor dê ênfase à relação existente entre esse conteúdo e a vida cotidiana dos alunos. Nesta perspectiva, o contexto no qual o sujeito está inserido é fator determinante para a consolidação da aprendizagem, o que significa que os materiais elaborados e utilizados em sala de aula devem estar alinhados com o mundo vivencial e, especialmente, estruturados em uma linguagem próxima do aluno.

A didática francesa tem mencionado a necessidade de que os conteúdos e os materiais utilizados sejam adaptados para as situações de ensino, mostrando por meio da transposição didática anunciada por Chevallard (1991) e seus seguidores, que a chegada do saber a ser ensinado sofre um conjunto de transformações até se consolidar como saber ensinado. Em outras palavras, o que está no livro didático, fruto de uma primeira transposição didática (saber sábio para saber a ser ensinado), sofre novamente uma transformação para se constituir em objeto de saber dentro do contexto da sala de aula. Isso, somado à perspectiva sociocognitivista, mostra que esta última adaptação precisa ser no sentido de considerar o contexto local, o mundo vivencial e a cultura na qual os estudantes estão imersos. O que justifica e valoriza as sequências didáticas e os materiais adaptados a cada realidade, como foi o caso do trabalho apresentado.

A partir dessas considerações, no seguimento deste trabalho e como terceira categoria de análise, avaliam-se os recursos didáticos utilizados no decorrer das aulas e, particularmente, se a metodologia utilizada pode ser considerada como favorecedora da interação social. O material das aulas foi preparado de acordo com a proposta sociointeracionista, tomando como aspecto central iniciar por um questionamento e oportunizar que os estudantes façam suas inferências a partir dele. Além disso, as atividades envolvendo aspectos lúdicos, como o jogo didático e as atividades experimentais, são objeto de discussão dessa categoria. Para tanto, recorre-se novamente aos registros do diário de bordo do pesquisador, como forma de buscar elementos para verificar os aspectos anunciados para essa categoria.

Tais registros estão indicados a seguir: 
Trazer o filme para a aula de hoje me fez notar que muitas vezes podemos trabalhar de uma maneira diversificada e, que isso faz com que os alunos se comprometam mais com as propostas do que apenas passar uma matéria no quadro negro, pois quando finalizamos o filme eles além de questionarem sobre a matéria já queriam saber quando teríamos outra atividade semelhante (DIÁRIO DE BORDO, 05/04/2018).

Hoje durante a aula trabalhamos com materiais como áudios, vídeos curtos e imagens. Durante as discussões muitos alunos puderam evidenciar que é mais fácil compreender os fenômenos em si quando conseguem visualizá-los e não apenas imaginar os mesmos (DIÁRIO DE BORDO, 19/04/2018).

A opção por utilizar os jogos se revelou favorável à aprendizagem, especialmente em termos de despertar a motivação para buscar o conhecimento. No jogo, os alunos se mostraram interessados e participativos, o que eu não havia percebido em outras atividades. O jogo precisa ser considerado uma estratégia de aprendizagem e ser levado mais vezes para dentro da sala de aula (DIÁRIO DE BORDO, 19/04/2018).

As atividades experimentais têm se constituído como uma importante ferramenta didática [...] o que pode ser observado na atividade desenvolvida na aula de hoje [quinto encontro]. Os alunos se mostraram eufóricos e envolvidos quando oportunizei que eles se movimentassem em sala de aula e pudessem vir até o equipamento didático. [...] A observação direta ainda se revela uma importante componente de aprendizagem, pelo menos em termos de aguçar a curiosidade dos alunos (DIÁRIO DE BORDO, 26/04/2018).

O evidenciado nos registros aponta que trazer ferramentas didáticas diferenciadas para a sala de aula possibilitou despertar o interesse dos alunos e oportunizando a compreensão dos fenômenos em estudo. A seleção dos recursos didáticos e sua estruturação representaram um apoio à aprendizagem, de modo a envolver os estudantes com o tema da aula. Isso leva a uma permanente reflexão do processo ensinoaprendizagem presentes no contexto da sala de aula, para além das trocas entre alunos e professores.

Particularmente, em se tratando da Astronomia, percebemos que a utilização de recursos didáticos envolventes, como o áudio que falava de Plutão, a atividade experimental relacionada à observação das fases da Lua, as imagens utilizadas, os questionamentos realizados, podem ser considerados como marcantes na formação deles, pois se diferenciam significativamente das atividades que tradicionalmente realizam em sala de aula. De acordo com Silva, Giordani e Menotti (2009, p. 9) os materiais didáticos devem ser atrativos, estimular a curiosidade e o interesse dos educandos, como também aguçar seus sentidos e facilitar a aprendizagem. Eles são responsáveis por favorecer a interação dos alunos, uma vez que devem ser organizados didaticamente, considerando as potencialidades e o limite de quem vai utilizá-lo. 
Dolz (1994) mostra que a compreensão de um texto, por exemplo, é fruto das interações que ocorrem entre o sujeito e o texto, o que está associado às vivências de cada um, pois são elas que vão dar significado à escrita. A compressão nesse sentido envolve dimensões estruturais e linguísticas que estão vinculadas a fatores sociais que vão produzir o entendimento e levar a aprendizagem. Dessa forma, a escolha de um texto, de uma atividade, requer conhecer a realidade dos estudantes, conhecer o mundo social e cultural, pois é por meio deles que os estudantes vão dar significado à atividade e construir seu entendimento sobre o fenômeno em estudo.

Os materiais didáticos utilizados nesta sequência de ensino mostram a sua potencialidade como processo de interação, se aproximando do que Castorina et al. (1998, p. 121) mencionam em termos dos processos de intervenção em sala de aula, os quais devem atuar "no sentido de orientar o desenvolvimento do aluno para que ele possa apropriar-se dos instrumentos de mediação cultural".

\section{Considerações finais}

O estudo realizado possibilitou identificar elementos que são favorecidos em uma prática pedagógica sociointeracionistas, apontando as potencialidades de um ensino de tópicos de Astronomia no ensino fundamental - anos finais. No estudo, a sequência didática elaborada teve como ênfase ofertar um conjunto de recursos didáticos aos professores, de modo a evidenciar a viabilidade de abordar a temática a partir de situações de ensino e de aprendizagem que favorecessem as trocas entre os envolvidos no contexto escolar. Para tanto, buscamos embasamento teórico no sociointeracionismo de Vigotski, evidenciando que as interações ocorridas entre aluno/aluno, aluno/professor e aluno/material se revelaram elementos que assumiram realce na proposta e possibilitaram evidenciar as suas potencialidades.

Em termos da perspectiva teórica selecionada para o estudo e no momento final a sua discussão, faz-se necessário evidenciar que, de acordo Vigotski (2003), o único bom ensino é aquele que se adianta ao desenvolvimento, ou seja, deve-se sempre caminhar no sentido de olhar para frente, de adiantar a aprendizagem, nunca de consolidar o que já está aprendido. Em outras palavras, o ensino deve priorizar aquilo que o estudante não tem condições de percorrer sozinho, mas que, com a ajuda do outro, consegue realizar. 
Isso nos mostra que os conteúdos de Astronomia que podem parecer, para alguns, com pouco significado no início do processo de escolarização, poderão servir para pôr em movimento um conjunto de estruturas cognitivas que favoreçam o desenvolvimento do aluno. Esse fazer com ajuda do outro, no caso específico da escola, é representado pelo professor, pelos colegas e pelos materiais didáticos utilizados.

$\mathrm{Na}$ abordagem sociointeracionista a construção de conhecimentos é concebida como processo constituído nas relações sociais, implicando o funcionamento interpessoal e a linguagem. O conhecer envolve mediação com o outro e produção de significados e sentidos em relação a objetos construídos culturalmente. A Astronomia, seus mitos e crenças fazem parte da cultura e, portanto, a escola deve se ocupar de trazer para dentro da sala de aula esses conhecimentos adquiridos de forma espontânea e transformá-los em científicos, sem desrespeitar o mundo vivencial, a cultura, mas possibilitar que os estudantes tenham conhecimentos suficientes para fazer suas escolhas.

Tais aspectos se revelaram presentes durante a investigação de modo que, ao findar esse estudo, mencionamos que a sequência didática elaborada oportunizou entre outros aspectos trocas entre os sujeitos envolvidos (alunos e professores), bem como dos alunos com o material utilizado; motivar os alunos para exposição de suas ideias, relato de experiências e apresentação de curiosidades vinculadas ao tema; estimular os alunos a serem protagonistas de sua própria aprendizagem, relegando a eles o papel de sujeitos ativos e responsáveis pelo processo de construção do conhecimento; emergir saberes das relações estabelecidas no âmbito interpessoal e que se constituíram como processos mentais internos (intrapessoal); mostrar o caráter cultural e social do conhecimento; que os alunos refletissem sobre os eventos presentes no mundo próximo e remoto, favorecendo se sentirem parte atuante da sociedade; e salientou o aspecto afetivo como fundamental para os processos educativos. Tais aspectos possibilitaram responder à pergunta central do estudo e se caracterizam como resultados do estudo.

Por fim, destacamos que a aprendizagem é um processo social, caracterizada pelas ações de uns sobre os outros, pelas diferentes linguagens utilizadas, construída por meio dos vínculos entre quem ensina e quem aprende. Assumem relevância nesse processo as interações sociais, mas também aspectos afetivos como os destacados nos resultados deste estudo. E é a partir deles que, ao finalizar este estudo, se anuncia a perspectiva de novas investigações, envolvendo aspectos relacionadas à afetividade, de modo a analisar quais 
as dimensões relacionadas a esse domínio são favorecidas por propostas didáticas sociointeracionistas como a apresentada neste estudo. A afetividade vem se caracterizando como um dos principais elementos relacionados a aprendizagem, estando entre os temas emergentes quando se trata do ensino de Ciências e Matemática no século XXI. Desta forma, sua vinculação com propostas didáticas urge como uma nova empreitada sobre a qual se pretende debruçar na continuidade desta pesquisa.

\section{Referências}

AMARAL, Denise de Souza. Estudo de uma sequência didática na perspectiva de Ausubel para alunos do sexto ano do Ensino Fundamental sobre Astronomia. 2015. Dissertação (Mestrado em Educação Matemática e Ensino de Física) - Universidade Federal de Santa Maria, Santa Maria, 2015.

BARroS, Célia Silva G. Psicologia e construtivismo. São Paulo: Ática, 1996.

CASTORINA, José A.; FERREIRO, Emilia; LERNER, Delia; OLIVEIRA, Marta Kohl de. Piaget e Vigotsky: novas contribuições para o debate. 5. ed. São Paulo: Ática, 1998.

CHEVALLARD, Yves. La Transposición didáctica: del saber sabio al saber enseñado. Buenos Aires: Aique, 1991.

COLE, Michael; SCRIBNER, Sylvia. "Introdução". In: VIGOTSKI, L. S. A formação social da mente. São Paulo: Martins Fontes, 2007.

DANIELS, Harry. Vygotsky e a pedagogia. São Paulo: Edições Loyola, 2003.

DOLZ, Joaquim. Produire des textes pour mieux comprendre. L'enseignemnt du discours argumentatif. In: Colloque de L'université Charles-de-Gaulle III. Neuchâtel, Anais... Neuchâtel: Peter Lang, 1994. p. 219-241.

FREIRE, Paulo. Pedagogia da autonomia. 36. ed. São Paulo: Paz e Terra, 2007.

GIL, Antonio C. Como elaborar projetos de pesquisa. 4. ed. São Paulo: Atlas, 2008.

PÉREZ GÓMEZ, Ángel I. Funções sociais da escola da reprodução à reconstrução crítica do conhecimento e da experiência. In: SACRISTÁN, José Gimeno; PÉREZ GÓMEZ, Ángel. I. Compreender e transformar e ensino. 4. ed. Porto Alegre: Artmed, 2000. p. 1326.

MARX, Karl; ENGELS, Friedrich. A ideologia alemã. São Paulo: Hucitec, 1999.

MARTINS, João Carlos. "Vigotski e o papel das interações sociais na sala de aula: reconhecer e desvendar o mundo”. Ideias, São Paulo, n. 28, p. 111-122, 1997. 
MEES, Alberto A. Astronomia: motivação para o ensino de Física na $8^{\mathrm{a}}$ série. 2004. Dissertação (Mestrado em Ensino de Física) - Instituto de Física, Universidade Federal do Rio Grande do Sul, Porto Alegre, 2004.

PALANGANA, Isilda C. Desenvolvimento e aprendizagem em Piaget e Vygotsky: a relevância do social. São Paulo: Summus, 2001.

RAMOS, Maria Beatriz J. As dificuldades de aprendizagem: leituras e desafios. In: LA ROSA, Jorge (Org.). Psicologia e educação: o significado do aprender. 4. ed. Porto Alegre: EDIPUCRS, 2001.

RATNER, Carl. A psicologia sócio-histórica de Vygotsky: aplicações contemporâneas. São Paulo: Artmed, 2002.

ROSA, Cleci T. Werner da. Laboratório didático de Física da Universidade de Passo Fundo: concepções teórico-metodológicas. 2001. Dissertação (Mestrado em Educação) Universidade de Passo Fundo, Passo Fundo, 2001.

A metacognição e as atividades experimentais no ensino de Física. Tese (Doutorado em Educação Científica e Tecnológica) - Universidade Federal de Santa Catarina, Florianópolis, 2011.

RICHARDSON, Roberto J. Pesquisa social: métodos e técnicas. São Paulo: Atlas, 1999.

RODRIGUES, Olga M. P. R.; MELCHIORI, Lígia E. Aspectos do desenvolvimento na idade escolar e na adolescência. Disponível em: https://acervodigital.unesp.br/bitstream/unesp/155338/3/unespnead_reei1_ee_d06_s01_texto01.pdf. Acesso em: 21 set. 2020.

SILVA, Evellyn L.; GIORDANI, Estela M.; MENOTTI, Camila R. As tendências pedagógicas e a utilização dos materiais didáticos no processo de ensino e aprendizagem. In: SEMINÁRIO NACIONAL DE ESTUDOS E PESQUISAS, 8, 2009, Campinas. Anais... Campinas: Unicamp, 2009. p. 1-5.

SOUZA, Solange J. Infância e linguagem: Bakhitin, Vygotsky e Benjamim. 8. ed. Campinas: Papirus, 2004.

TASSONI, Elvira Cristina M. Afetividade e aprendizagem: A relação professor-aluno in Psicologia, análise e crítica da prática educacional. Campinas: ANPED, 2000, p. 6.

TUDGE, Jonathan. Vygotsky a zona de desenvolvimento proximal e a colaboração entre pares: implicação para a prática em sala de aula. In: MOLL, Luís C. Vygotsky e a educação. Porto Alegre: Artes Médicas, 1996.

VIGOTSKI, Lev Semenovich. A formação social da mente. São Paulo: Martins Fontes, 1984. 
267 Polyphonía, v. 31/2, jul.-dez. 2020

. Linguagem, desenvolvimento e aprendizagem. 9. ed. São Paulo: Ícone, 2005.

ZABALZA, Miguel A. Diários de aula: um instrumento de pesquisa e desenvolvimento profissional. Porto Alegre: Artmed, 2004.

Recebido em: 24 jul. 2019.

Aceito em: 21 set. 2020. 


\title{
O Pacto pela Alfabetização na Idade Certa em Goiás - PNAIC: A Formação em Serviço e seus Desafios
}

\author{
Edna Silva Faria* \\ Amone Inacia Alves**
}

\begin{abstract}
Resumo
Este trabalho resulta da reflexão sobre formação realizada em Goiás, intitulada: Pacto pela Alfabetização na Idade Certa - PNAIC. Essa proposta adveio em 2013, de uma expectativa do Ministério da Educação e Cultura (MEC) em qualificar professores atuantes no ciclo de alfabetização, de modo que fossem capazes de refletir sobre os conceitos, práticas e significados do processo de alfabetizar, contribuindo para um debate de âmbito nacional. No Brasil, a formação de professores alfabetizadores ainda é pífia, impactando sobretudo nos resultados demonstrados. Em Goiás, esse Programa foi responsável pela qualificação de quatorze mil professores alfabetizadores, coordenadores e demais profissionais escolares. Compreendeu-se que, sem o investimento dessa ação, não seria possível a inserção dos alfabetizadores na discussão e na implementação de novas práticas e metodologias. Neste texto, adotando como metodologia a revisão bibliográfica, refletimos como o esclarecimento contribuiu para esse processo, ressaltando o papel da interdisciplinaridade. O Programa utilizou material elaborado especificamente para o PNAIC, portanto este artigo aborda também a perspectiva de interdisciplinaridade adotada na elaboração dos materiais de suporte - os cadernos do PNAIC - e nos materiais de apoio - caixa de jogos e atividades - adotados como auxílio no processo de formação.
\end{abstract}

Palavras-chave: formação em serviço, interdisciplinaridade, PNAIC.

Pacto pela Alfabetização na Idade Certa em Goiás (PNAIC): Training in Process and the Challenges

\begin{abstract}
This article results of a reflection about an experience developed in the State of Goias: Pacto pela Alfabetização na Idade Certa - PNAIC (Pact for Literacy at the Right Age). The Project was created in 2013, by the Ministry of the Education and Culture - MEC with the propose to qualify teachers who work in the circle of literacy, with the purpose to help them to reflect about concepts, practices and the meaning of the process of literacy, giving some contribution to a national debate about the subject. In Brazil, the training of literacy teachers is still poor, which impacts, above all on the results demonstrated. In the State of Goiás, this program was responsible for the qualification of fourteen thousand literacy teachers, coordinators and other school professionals. It was understood that without the investment of this action, it would not be possible to insert the literacy teachers in the discussion and implementation of new practices and methodologies. In this text, and adopting bibliographic revision as methodology, we reflected how enlightenment can contribute to this process, standing out to the interdisciplinarity. The Program used material specifically developed for the PNAIC, so this article also addresses the perspective of interdisciplinarity adopted in the elaboration of support materials - PNAIC notebooks - and the support materials - box games and activities, adopted as support in the formation process.
\end{abstract}

Keywords: training process, interdisciplinarity, PNAIC.

\footnotetext{
* Doutora em Letras e Linguística pela FL/UFG. Professora adjunta da FL/UFG. E-mail: edna_faria@ufg.br.

** Doutora em Educação pela FE/UFG. Professora associada da FE/UFG. E-mail: amoneinacia@gmail.com.
} 


\section{Introdução}

Este trabalho ${ }^{1}$ visa a demonstrar como se desenvolveu o Pacto pela Alfabetização na Idade Certa - PNAIC - em Goiás. Esse Programa foi estabelecido pelo MEC em 2012, pela Portaria $\mathrm{n}^{\mathrm{o}}$ 867, de 4 de julho de 2012, objetivando qualificar os professores alfabetizadores, em atendimento à meta 5 do Plano Nacional de Educação (PNE) e à meta 20, quanto à valorização e capacitação desses profissionais e pela garantia dos direitos de aprendizagem e desenvolvimento.

No Estado de Goiás, os trabalhos iniciaram no ano de 2013, inseridos em um contexto de precariedade de formação dos professores dessa fase do ensino, aliado aos pífios resultados da alfabetização no Estado, cujo índice era de 10,8\% em 2000, diminuindo para 7,3\% na década seguinte. Caberia à Universidade desenvolver a proposta, alinhavando junto às demais instituições formadoras do Estado, Universidade Estadual de Goiás (UEG) e Pontifícia Universidade Católica (PUC), uma proposta de formação que conseguisse dirimir essas questões e fornecesse subsídios para um trabalho mais eficaz e eficiente no âmbito da alfabetização.

Foram firmadas parcerias com duzentos e vinte e quatro municípios, envolvendo secretários municipais de Educação, gestores, professores alfabetizadores e demais profissionais interessados em compreender conceitos, estratégias e metodologias de alfabetizar. Se tratava de uma política inovadora, uma vez que os parceiros envolviam Universidades e não institutos privados, na contratação de empresas que empreendiam essas formações, como era tradição no Estado.

Considerando a relevância do tema para as discussões sobre alfabetização e erradicação do analfabetismo, é objeto deste texto descrever como se deu o trabalho formativo desse Programa, além de apresentar dados sobre o alcance dos resultados nos índices do Estado, principalmente por se tratar de um Programa voltado para a formação continuada.

Embora haja polissemia dos conceitos, entendemos por formação, em Kant (2006), a necessidade do esclarecimento e da moralidade, cuja intenção não se atende ao treinamento e à disciplina. Nesse sentido, coube-nos inquirir se é possível em um curso

\footnotetext{
${ }^{1}$ Este artigo é fruto de uma pesquisa desenvolvida após a realização do processo de formação em serviço na proposta do Pacto pela Alfabetização na Idade Certa - PNAIC. Este trabalho foi apresentado no CONEPI, realizado em 2017, e publicado nos anais do evento. Para esta publicação, foram feitas alterações.
} 
de formação com características particulares como o que propõe o PNAIC avançar em termos conceituais, indo além da perspectiva pragmática de passar metodologias aos professores alfabetizadores, bem como levantar o que desejavam os professores alfabetizadores ao cursarem os módulos de formação do PNAIC.

Diante dessas indagações, foi formulado um questionário de avaliação e entregue aos participantes do Programa para que se posicionassem quanto a essas e a outras perguntas. Portanto, a proposta deste trabalho é apresentar os dados, que são reveladores para se pensar em um Programa de grande abrangência como o PNAIC e o papel da Universidade na construção e no desenvolvimento de uma proposta de formação em serviço.

\section{A escolha de um conceito de formação}

Quando analisamos o perfil do profissional que atua na alfabetização das crianças, partimos do pressuposto de que a alfabetização envolve uma série de aspectos que precisam ser pensados pelo professor, tais como: as concepções de ensino e de aprendizagem, a proposta de formação dos alunos e mesmo o entendimento dos conteúdos a ser ensinados. Além disso, urge a necessidade de compreender quem é esse sujeito que ensina e em quais aspectos ele precisa se guiar, de modo a tornar-se um bom professor ou alfabetizador.

Nesse sentido, entendemos que as licenciaturas, sobretudo a de Pedagogia, nem sempre conseguem ter nos currículos disciplinas que englobem a alfabetização e sua prática como objeto de análise. Por exemplo, na matriz do Currículo de Pedagogia da Faculdade de Educação da UFG, apenas uma disciplina se ocupa da alfabetização e do letramento. O pedagogo formado sente a necessidade de discutir sobre metodologias de alfabetização, muitas vezes acreditando que nesse ponto reside a saída para as suas dificuldades em sala de aula. Não discordamos que o enfoque metodológico seja necessário, mas a compreensão da alfabetização como um fenômeno social, que tem a sua historicidade e está ligada a um trabalho formativo mais amplo, deve ser o início de todo projeto de sociedade e de escola.

Embora a escola seja o lócus privilegiado onde se dá o ensino-aprendizagem, a leitura de mundo precede a leitura escrita e está por toda parte, retomando Paulo Freire, 
nos diversos espaços onde crianças aprendem o tempo todo. Sem querer esbarrar na perspectiva redentorista, o professor que atua nesse nível de ensino participará ativamente da formação das crianças, cabendo-lhe desde o cuidado com as primeiras letras, até o diálogo com a realidade na qual vive. Partindo dessa perspectiva, tomaremos o conceito de formação segundo Kant, a partir do que ele designa como educação moral:

\begin{abstract}
A pedagogia, ou doutrina da educação, se divide em física e prática. A educação física é aquela que o homem tem em comum com os animais, ou seja, os cuidados com a vida corporal. A educação prática ou moral (chama-se prático tudo o que se refere a liberdade) é aquela que diz respeito à construção (cultural) do homem, para que possa viver como um ser livre (KANT, 2006, p. 36).
\end{abstract}

$\mathrm{Na}$ formação da cultura, o diálogo toma como ponto de partida a realidade do aluno e como ponto de chegada outras realidades, cabendo-lhe o papel de apresentar a universalidade. Esse cosmopolitismo é importante para a formação geral, pois envolve o entendimento da cultura como um bem universal e a necessidade constante de humanizarse. Kant (2006) assevera que a educação, no afã de instruir o homem dentro da perspectiva da moralidade, deve produzir a humanidade, seja no trato com as outras pessoas, ou no sentimento. A moralidade se fundamenta nos conceitos da razão pura, pois de acordo com Kant (2006, p. 229) “age de tal maneira que usa a humanidade, tanto na tua pessoa como na pessoa de qualquer outro, sempre e simultaneamente como um fim e nunca como meio". Observamos, nesse excerto, que Kant chama a atenção para o fato de que a finalidade máxima da educação deve ser o entendimento do outro, quanto aos seus valores, desejos e direitos, partindo-se da ideia de alteridade.

Ainda que a lei moral seja transmitida a todos, a razão não age com espontaneidade, sendo necessária a participação de outrem, no caso específico abordado aqui do professor alfabetizador. Contudo a formação humana é um processo que envolve a formação de um "sujeito livre, racional e moralmente bom", mas que se cria a partir de si mesmo, no exercício com o outro. Aí residem os limites, segundo essa visão, do papel do professor.

A formação humana é dividida em duas etapas. Na primeira, o homem é heterônomo, não sendo ainda um ser emancipado, sem a capacidade de emancipar-se, dependente dos outros. Nessa etapa, ele precisa ser disciplinado e instruído, seja pela família, demais instâncias sociais e pela escola, e o investimento da educação deve ser 
contínuo, pois há responsabilidades e riscos no ato de educar. Já na segunda etapa, esse mesmo homem adquire características autônomas, sendo capaz de assumir a sua própria formação. Notamos que Kant (2006, p. 15) valoriza em demasia esse processo, assumindo que o homem torna-se "aquilo que a educação faz dele".

Nesse propósito, a educação moral visa a aperfeiçoar o caráter moral dos educandos, instruindo-os sobre a necessidade de se submeter aos deveres morais. Existe uma lei moral que exige conformidade aos princípios da sociedade, sendo tarefa da educação desenvolver qualidades no sujeito que aprende. O conhecimento é o caminho para que o projeto educativo se desenvolva, pois sem ele não há possibilidades de aperfeiçoamento. Considerando o processo de desenvolvimento, Kant relaciona a educação à arte:

\footnotetext{
A educação é uma arte, cuja prática necessita ser aperfeiçoada por várias gerações. Cada geração, de posse dos conhecimentos das gerações precedentes, está sempre melhor aparelhada para exercer uma educação que desenvolva todas as disposições naturais na justa proporção e de conformidade com a finalidade daquelas e, assim, guie toda a humanidade espécie ao seu destino (KANT, 2006, p. 19).
}

Daí a importância de se relacionar a aprendizagem com o passado, com o vivido, o já realizado na formação de professores, de modo a estimulá-los a refletir sobre as práticas que adotam, sobre as experiências que vivenciam no fazer docente, permitindo que conheçam o processo educativo e suas bases conceituais. Por isso é fundamental que os cursos de formação de professores incidam esforços para o desenvolvimento de práticas envolvendo o conhecimento do passado, do experimentado, do saber empírico, a fim de se construir uma reflexão e um esclarecimento dos usos que foram feitos destes.

Convém pensar em uma formação abrangente, com uma perspectiva de alargar os conhecimentos sobre educação, instrução, formação e infância, porém um curso de graduação, pelo tempo desprendido, não seria capaz de contemplar esse feito. Daí a necessidade da formação continuada, chamada formação em serviço, organizada de forma a capacitar o docente para os desafios do seu trabalho.

\section{A formação continuada: em busca de uma análise interdisciplinar}

O PNAIC proporcionou ações voltadas à formação continuada de professores, uma ação continuada pensada pelo MEC, em conjunto com as Universidades e as 
secretarias de educação, visando a qualificar os professores que atuam na alfabetização, entendendo essa etapa como decisiva na formação das crianças. Por possuir uma perspectiva interdisciplinar, compreendia que o profissional atuante nos anos iniciais da formação desses estudantes deveria dispor de diversos conhecimentos que possibilitassem um alargamento da visão de mundo, considerando o contexto escolar. Sobre interdisciplinaridade entendemos o acordo

de um saber com outro saber, ou dos saberes entre si, numa sorte de complementaridade, de cumplicidade solidária, em função da realidade estudada e conhecida. Nem poderia ser de outra forma, porquanto qualquer conhecimento, o mais abrangente que seja, será sempre parcial, jamais expressando plenamente a verdade do objeto conhecido, muito menos a sua inteireza, amplitude e totalidade (COIMBRA, 2016, p. 72).

Essa visão interdisciplinar necessária nos permite acreditar que a alfabetização sem o diálogo necessário com outras áreas do saber é uma ação inócua, pois afinal, a leitura de mundo, nas diversas áreas de conhecimento, precede a leitura de um texto e, a partir dessa concepção, o professor alfabetizador assume a tarefa de ser o interlocutor dessas diferentes linguagens, contextos e práticas escolares.

A interação é fundamento para que o processo de aprendizagem ocorra, num movimento de troca e partilha entre os pares e, nos dizeres de Fazenda (1995, p. 10) "é uma relação de reciprocidade, de mutualidade, que pressupõe uma atitude diferente a ser assumida diante do problema do conhecimento, ou seja, é a substituição de uma concepção fragmentária para unitária do ser humano".

Uma concepção unitária pressupõe diálogo e abertura para as possibilidades que se apresentam, numa atitude de engajamento, em que se firma um compromisso pessoal em direção ao entendimento, de vivências conjuntas, pautadas na partilha e na integração entre os envolvidos. Observamos no PNAIC que a interdisciplinaridade é um dos pilares norteadores para o trabalho de formação, pois constrói-se e orienta-se a partir da integração, seja no que se refere aos conteúdos, seja no que se refere às ações e atividades propostas e, para que isso ocorra, precisa estar associada a uma prática contextualizada.

Tratar da interdisciplinaridade no contexto escolar pressupõe uma mudança no modo de gestão e de organização das atividades pelo movimento da integração. Fazenda (1995, p. 12) ressalta que a interação é “condição de efetivação da interdisciplinaridade. Pressupõe uma integração de conhecimentos visando novos questionamentos, novas 
buscas, enfim, a transformação da própria realidade, num engajamento comum e coletivo".

Observamos, na constituição conceitual do PNAIC, o esforço por uma ação em rede que é demonstrada e está presente no material produzido, que subsidia e orienta o repertório teórico a ser adotado para a formação dos professores, fato evidenciado quando, no Caderno de Apresentação, afirma-se:

\begin{abstract}
O trabalho com os professores alfabetizadores com este conjunto de cadernos tem a tarefa de ampliar as discussões sobre a alfabetização na perspectiva do letramento, numa abordagem interdisciplinar. O processo de formação privilegia um diálogo permanente e sistemático com a prática docente e com a equipe pedagógica da escola para a garantia dos direitos de aprendizagem e desenvolvimento dos estudantes e para a melhoria da qualidade do ensino público brasileiro (BRASIL, 2015, p. 7).
\end{abstract}

Esse posicionamento demonstra a preocupação de oferecer uma formação pautada na construção coletiva, na troca de saberes, no engajamento dos participantes e na mobilização da comunidade escolar para a garantia dos direitos de aprendizagem dos estudantes. Dessa forma, observa-se que um dos pontos relevantes do PNAIC é o investimento na formação profissional pela prática da reflexividade, a partir da vivência cotidiana das práticas e da compreensão da necessidade de uma retomada dos aspectos teóricos e dos fundamentos do processo de alfabetização e letramento.

A retomada de uma práxis docente reflexiva associa-se à constituição da identidade profissional, uma vez que leva o professor a realizar um exercício constante sobre sua atuação em sala, sobre os conhecimentos que têm, as necessidades e demandas que surgem no dia a dia no contexto escolar e as estratégias adotadas para a resolução dos problemas e das dificuldades apresentadas pelos alunos.

Pensar sobre a própria prática requer um esforço e reconhecimento das competências, habilidades, possibilidades e entraves no exercício docente, com a percepção do movimento de permanente construção profissional, de estar em constante formação. Essa percepção é primordial ao engajamento na atuação e permite que, aos saberes existentes, unam-se outros advindos e adquiridos por meio de estudos, de pesquisas e da atitude de colaboração entre os pares, efetivando a aprendizagem coletiva de todos os envolvidos e a colaboração, conforme destaca o Caderno de Apresentação: 
para além da socialização, trata-se de um elemento fundamental no processo de formação. Através da colaboração, busca-se a formação de uma rede que visa ao aprendizado coletivo, por meio do qual os professores exercitem a participação, o respeito, a solidariedade, a apropriação e o pertencimento (BRASIL, 2015, p. 28).

A percepção de um trabalho organizado em sistema de rede e de colaboração encontra respaldo nos pensamentos de Kant, pois pelo conhecimento e consciência da realidade que o cerca, esse profissional constrói sua própria consciência e realidade, e pode interferir sobre ela, sendo mediador de suas aprendizagens às quais vão se agregando outros saberes, por isso, conforme apontam os cadernos do PNAIC (2015, p. 12) "essa integração não pode ser pensada apenas no nível de integração de conteúdos ou métodos, mas basicamente no nível de integração de conhecimentos parciais, específicos, tendo em vista um conhecer global".

Por muito tempo, as discussões referentes à interdisciplinaridade estiveram direcionadas aos anos finais do ensino fundamental e do ensino médio, porém no que se refere ao PNAIC, pela sua configuração e finalidade, para se realizar um trabalho de alfabetização diferenciado e articulado, o caminho possível se dá somente pelo trabalho interdisciplinar, unindo ao processo de alfabetização o letramento e os conhecimentos e conteúdos dos demais componentes curriculares. Nesse sentido, o material PNAIC coloca como objetivos: a) compreender o conceito de interdisciplinaridade e sua importância no Ciclo de Alfabetização; b) compreender o currículo em uma perspectiva interdisciplinar; c) refletir sobre como crianças e professores avaliam experiências de aulas desenvolvidas em uma perspectiva interdisciplinar; d) conhecer possibilidade do uso da leitura no trabalho interdisciplinar; e) conhecer, analisar e planejar formas de organização do trabalho pedagógico como possibilidades de realização de um trabalho interdisciplinar, mais especificamente, por meio de sequências didáticas e projetos no Ciclo de Alfabetização.

É importante observar que, no histórico do tema da interdisciplinaridade, o sentido inicial atribuído à palavra disciplina - ordem - levou a um entendimento de organização curricular limitada a matérias e conteúdos que seriam trabalhados individualmente, sem conexão com outras áreas do saber, restringindo o conhecimento a blocos constituídos na sua especificidade e de maneira fragmentada e compartimentada. 
Ainda é uma constante no cotidiano das escolas em todo o território nacional a sistematização do processo ensino-aprendizagem na perspectiva fragmentada, embora esteja prevista na LDB $n^{\text {o. }} 5.692 / 71$, nos Parâmetros Curriculares Nacionais e nas Orientações Curriculares Nacionais. Conforme apontam os autores do Caderno 3, muitos professores ainda não sabem como fazer acontecer a interdisciplinaridade e a integração “acreditamos que a mudança de atitude para um trabalho interdisciplinar virá com o compromisso pactuado, integrando todas as dimensões de ensino: a pedagógica; a política; e a institucional", referindo-se a André (2005, p. 28).

Tratar do tema da interdisciplinaridade é repensar o processo de formação docente e as diretrizes que orientam a composição das matrizes, a organização das disciplinas, a seleção dos conteúdos a serem trabalhados durante o curso. Esses elementos interferem diretamente na formação dos professores e não necessariamente lhes oferecem condições de refletirem sobre a própria prática, daí esses profissionais demonstrarem empiricamente que sabem o que é interdisciplinaridade, no entanto, demonstram também a carência de estratégias que subsidiem o planejamento de um trabalho interdisciplinar pautado na integração, na partilha e no engajamento entre os membros da comunidade escolar. Notamos que, no que se refere aos pontos fundamentadores do PNAIC, a crença de que o trabalho interdisciplinar resulta da pactuação estabelecida, porque

a interdisciplinaridade se faz em torno de um processo que envolve a integração e o engajamento de educadores, gerando a interação das disciplinas do currículo escolar não apenas entre si, mas, sobretudo destas com a realidade, com vistas a superar a fragmentação e a formar integralmente os alunos (MENDES, GOMES e SILVA, 2015, p. 11).

Conforme os apontamentos constantes nos cadernos do PNAIC, uma das estratégias para que se efetive e fortaleça a interdisciplinaridade no contexto escolar é a organização do tempo associada ao planejamento coletivo, em que são selecionados os conteúdos e definidas as metodologias mais adequadas para o tratamento daquele conteúdo, assim é fundamental:

pensar na seleção, organização e distribuição de conhecimentos relevantes para que todos os estudantes possam se apropriar deles, a fim de atuarem na mudança de seus contextos como sujeitos autônomos, críticos e criativos. Por serem vistos como meios, e não fins, os conhecimentos devem ser abordados pelos professores em situações dinâmicas e reflexivas, por meio do 